\title{
Effect of Contraceptive Pills, Fungal Alkaloids and Wild Carrot Seeds Oil on Apoptosis in Albino Female Mice Lymphocytes

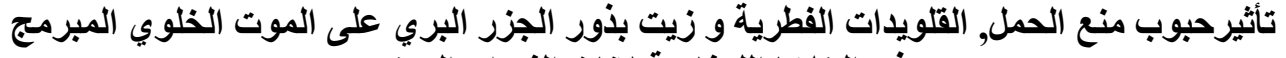

Worood K. Shalish

Saad M. Nada*

Abdalgani I. Yahya**

College of Education,Ibn Al-Haitham/ Baghdad University

Biotechnology Research Center/Al-Nahrain University* College of Science/ Al-Nahrain University**

عبد الغني ابراهيم يحيى**

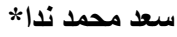

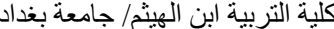

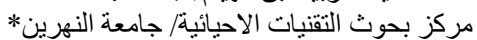

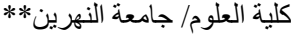

\begin{abstract}
This study compared three types of contraceptives agents by measuring the percentage of programmed cell death (apoptosis). Anti-fertility agents included contraceptive pills (Yasmin), fungal alkaloids (Cafergot) and the oil extract of the wild carrot seeds Daucus carota. Comparison process depended on the evaluation of apoptosis percentage in mice lymphocytes, that treated orally for five successive days with the contraceptive agents by using the concentration of $(60 \mu \mathrm{g} / \mathrm{kg})$ of Yasmin pills, $(20 \mu \mathrm{g} / \mathrm{kg})$ of Cafergot and $(0.1 \mathrm{ml})$ of wild carrot seeds oil. These were compared with the negative and positive control methotrexate (MTX) $(50 \mu \mathrm{g} / \mathrm{kg})$. Results showed that the percentage of apoptosis by using wild carrot seeds oil was $0 \%$ which was the least in comparison to contraceptives and equal to the negative control $0 \%$. On the other hand, there were no significant differences in the percentage of apoptotic cells with Cafergot treatment $0.1 \%$ in comparison with the negative control, while Yasmin pills treatment led to a significant increases $(\mathrm{P} \leq \mathbf{0 . 0 5})$ in apoptosis percentage to $0.6 \%$ in comparing to negative control. This response also significantly increased $(\mathbf{P} \leq \mathbf{0 . 0 5})$ in MTX treatment reaching $1.8 \%$. As conclusion the results of this work showed that, the oral contraceptive pills (Yasmin) was the most inducing contraceptive drugs to apoptosis, while Cafergot and wild carrot seeds oil were the least effective in comparison to the negative and positive control.
\end{abstract}

Key words: apoptosis, Yasmin, Cafergot, Daucuscarota, MTX.

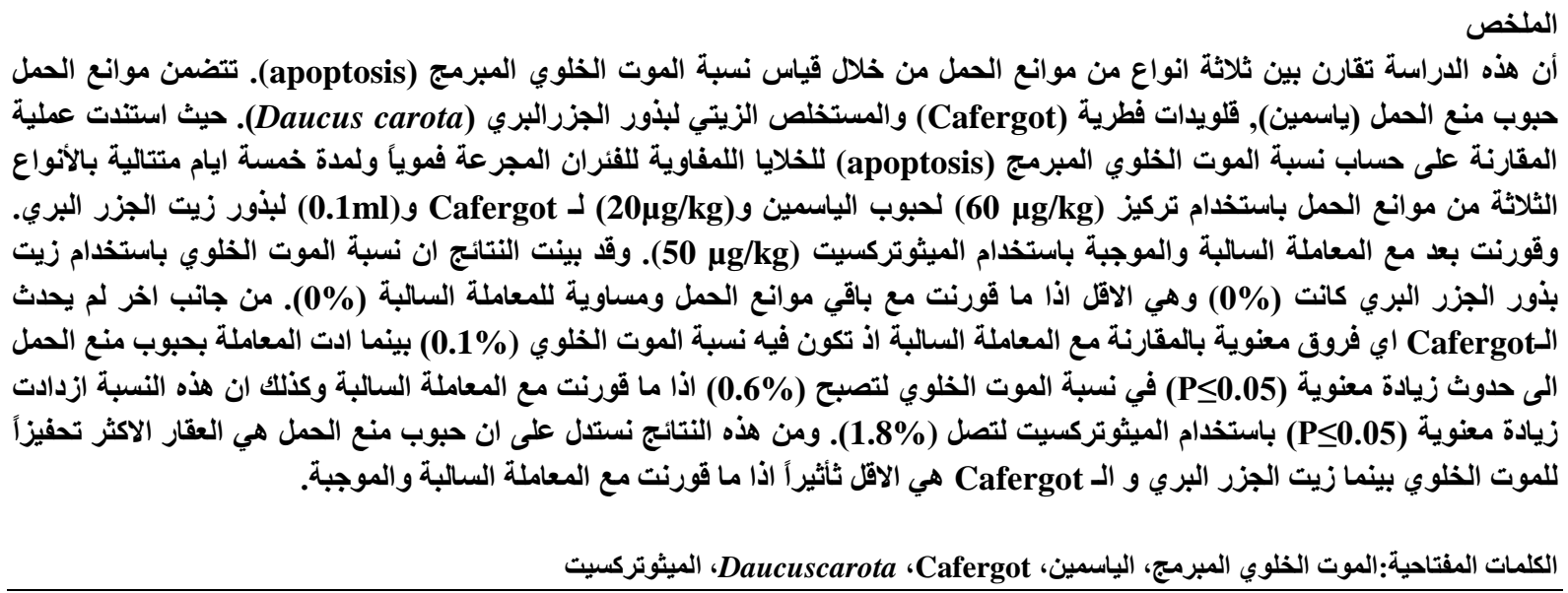
Introduction

Contraception is prevention of fertilization of an egg by a sperm (conception) or attachment of the fertilized egg to the lining of the uterus [1].The Egyptian Ebers Papyrus from 1550 BCE and the Kahun Papyrus from 1850 BCE have within them, some of the earliest documented descriptions of birth control, by using honey and acacia leaves, while in medieval Europe any effort to halt pregnancy was deemed immoral by the Catholic Church [2]. Birth control methods have been used since ancient times, but effective and safe methods only became available in the 20th century [3].Gregory Pincus and John Rock with help from the Planned Parenthood Federation of America developed the first birth control pills (BCPs) [4]. Oral contraceptives pills (OCPs) are 
medicines taken by mouth to help prevent pregnancy which contain synthetic forms of two hormones produced naturally in the body; these hormones are estrogen and progestin [5]. Yasmin is a combined oral contraceptive tablet containing the synthetic progestogen, drospirenone and the synthetic estrogen, ethinyloestradiol[6] and for the majority of women, oral contraceptives can be taken safely but there are some women who are at high risk of developing certain serious diseases that can be life-threatening or may cause temporary or permanent disability or death [7].

Numerous herbs have been used historically to reduce fertility, and modern scientific research has confirmed anti-fertility effects in some of the herbs tested [8] and wild carrot (Queen Anne's lace) has been used because of its contraceptive properties [9]. In addition microorganisms such as fungi offer a huge source of pharmaceutically useful molecules [10]. The ergot alkaloids (EA) are among the most important natural pharmaceuticals and toxins in human history, which is derived from the fungus Clavicepspurpurea[11]. Ergot extract has been used in pharmaceutical preparations, such as Cafergot (containing caffeine and ergotamine)[12]. EAs have been used for millennia to aid childbirth, birth control, treatment of migraines and, recently, treatment of Parkinsonism and other central nerve system disorders [13].

Apoptosis is the process of programmed cell death (PCD) that may occur in multicellular organisms. It is morphologically characterizedby cell shrinkage, membrane blebbing, nuclearcondensation, and formation of apoptotic bodies [14].

Aims of the study

The main aim of this investigation is to evaluate the programmed cell death by examining the apoptosis percentage in the cells using flow cytometry.

\section{Materials and methods}

\section{Animal grouping and treatment}

Fifteen female of Swiss albino mice BALB/c, their age was ranged between (8-12) weeks were used in this investigation and treated with the effective dose as a contraceptive of combined oral contraceptive pills, Cafergot pills and wild carrot seeds oil for 5 successive days. OCPs were obtained from Bayer Schering Pharma company/Germany, Cafergot was obtained from Novartis Pharma, while wild carrot seeds oil from Janat AlAshab herbarium that imported the plant extract from the world of herbs/ Bahrain.

Five groups of mice(3 mice)were used for this investigation and treated as follows:

- $\quad$ Group I: Negative control.

Treated with $(0.1 \mathrm{ml})$ of (D.W).

- $\quad$ Group II: Positive control. Treated with $(0.1 \mathrm{ml})$ of MTX $(50 \mu \mathrm{g} / \mathrm{kg})$.

- Group III: Combined oral contraceptive pills treatment. Treated with $(0.1 \mathrm{ml})$ of combined oral contraceptive pills $(60 \mu \mathrm{g} / \mathrm{kg})$.

- Group IV: Cafergot pill treatment. Treated with $(0.1 \mathrm{ml})$ of Cafergot pill $(20 \mu \mathrm{g} / \mathrm{kg})$.

- Group V: Wild carrot seeds oil treatment.

Treated with $(0.1 \mathrm{ml})$ of wild carrot seeds oil.

Drugs were given orally for 5 successive days. Blood samples were taken from mice heart, and the analyses of apoptosis were carried out as described later.

\section{Principle}

Apoptosis is a regulated cell death process characterized by morphological and biochemical features occurring at different stages. One of the plasma membrane alterations during apoptosis was the translocation of phosphatidylserine (PS) from the inner side of the plasma membrane to the outer layer, by which PS becomes exposed at the external surface of the cell. Detection of such membrane changes by Annexin $\mathrm{V}$ has been suggested as a suitable assay of early apoptotic cells [15].

\section{Kit contains}

Annexin V-FITC was employed in flow cytometry and performed according to the human Annexin V-FITC KitEXBio Praha. Reagents provided with the kit are binding buffer (10X concentrated), Annexin V-FITC, and Propidium iodide [16]. 


\section{Assay procedure}

\section{Preparation of reagent}

The Annexin V binding buffer was a 10x concentrated and diluted with deionized water prior to use in order to prepare 1x Annexin $\mathrm{V}$ binding buffer.

\section{Procedure}

1. Cells were harvested by centrifugation at 2,000 rpm for $5 \mathrm{~min}$, supernatant was discarded. Pellets were resuspended in cold PBS and cells were washed by gentle shaking or pipetting up and down. Re-centrifuged was hed cells again and supernatant was discarded.

2.Pellets were resuspended with $1 \mathrm{X}$ binding buffer and a just cell density to $2-5 \times 10^{5}$ cells $/ \mathrm{ml}$. preparing a sufficient volume of cell suspension $(100 \mu \mathrm{l} /$ assay).

3. Cells were stained with $5 \mu 1$ of Annexin V-FITC and propidium iodide (PI) and incubated for 15 minutes in dark at room temperature.

4. After the incubation period, cells were harvested by centrifugation at 2,000 rpm for 5 min, pellets were resuspended in $100 \mu$ l of binding buffer

5. The mixture was then analyzed by Flow Cytometry [16].

\section{Statistical analysis}

Analysis of variance was performed to test whether group variance was significant or not, the comparison between groups were conducted using statistical package for the social sciences (SPSS)program.

\section{Results and discussion}

Differentiating between cells of either apoptosis or necrosis was carried out using Annexin V-FITC kit. The different labeling patterns in this assay identify the different cell populations, e.g., region A: necrotic cells (PIpositive/ annexin V-negative); region B: late apoptosis (secondary necrosis) (PI-positive/annexin V-positive) region C: vital cells (PI-negative/ annexin V-negative); region D: apoptotic cells (PI-negative/annexin Vpositive).

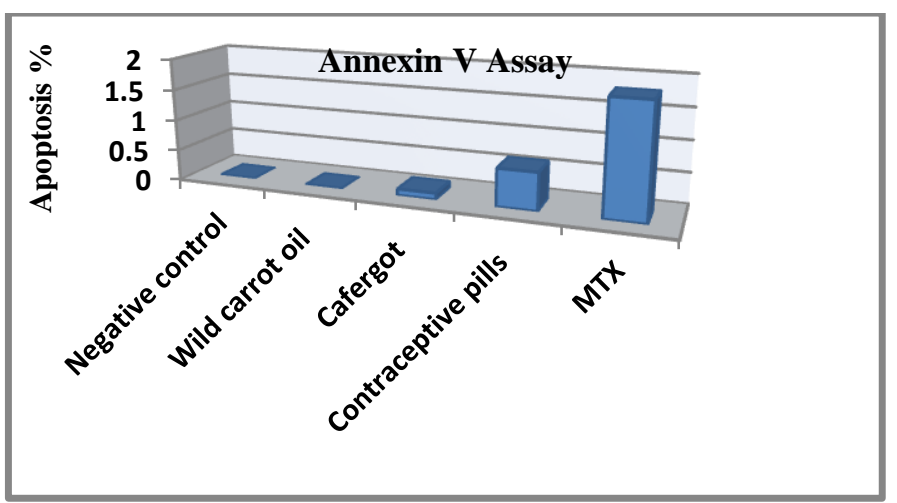

Fig.(1): Histograms showing the apoptosis percentage in lymphocyte from mice treated with contraceptives in comparison with the control by Annexin V assay

The results of these five groups illistrated in Figure (1), the percentage of apoptosis using wild carrot seeds oil was $0 \%$ which was the least as compared with contraceptives and equal to the negative control $0 \%$. Also, there was no observed increases in the percentage of apoptotic cells with Cafergot treatment $(0.1 \%)$ as compared with the negative control, while Yasmin pills led to increase in apoptosis percentage to $(0.6 \%)$ and also increased in MTX treatment to (1.8\%).The results of the present study using the apoptosis assay demonstrated that handling contraceptive pills and MTX were associated with a significant increases $(\mathrm{P} \leq 0.05)$ in apoptosis percentage in mice bone marrow while Cafergot treatment led to non- significant variation. The conclusion from these results showed that the oral contraceptive pills (Yasmin) is the most inducing contraceptive drugs on apoptosis while Cafergot and wild carrot seeds oil are the least effective as compared with the negative and positive control, Table (1) and figure (2). 
Table (1): Apoptosis percentage in lymphocyte isolated from mice by flow cytometry.

\begin{tabular}{|c|c|c|c|c|}
\hline Groups & $\begin{array}{c}\begin{array}{c}\text { Necrotic } \\
\text { cells-A }(\%) \\
(\text { mean }+ \text { SD })\end{array} \\
\end{array}$ & $\begin{array}{c}\text { Late apoptosis } \\
\text { cells-B }(\%) \\
(\text { mean } \pm \text { SD) }\end{array}$ & $\begin{array}{l}\text { Viable cell-C }(\%) \\
(\text { mean }+ \text { SD })\end{array}$ & $\begin{array}{l}\text { Apoptotic cells-D (\%) } \\
\left(\text { mean }_{ \pm} \mathrm{SD}\right)\end{array}$ \\
\hline Negative control & $\begin{array}{c}\mathrm{A} \\
0.24 \pm 0.02\end{array}$ & $\begin{array}{c}\mathrm{A} \\
0.1 \pm 0.01\end{array}$ & $\begin{array}{c}\mathrm{A} \\
99.66 \pm 1.25\end{array}$ & $\begin{array}{c}A \\
0.00 \pm 0.00\end{array}$ \\
\hline Methotrexate & $\begin{array}{c}B \\
1.60 \pm 0.1\end{array}$ & $\underset{0.4 \pm 0.01}{A}$ & $\begin{array}{c}\text { B } \\
96.2 \pm 2.4\end{array}$ & $\begin{array}{c}\text { B } \\
1.8 \pm 0.14\end{array}$ \\
\hline $\begin{array}{c}\text { Contraceptive pills } \\
\quad(60 \mu \mathrm{g} / \mathrm{kg})\end{array}$ & $\begin{array}{c}B \\
1.34 \pm 0.02\end{array}$ & $\underset{0.2 \pm 0.005}{A}$ & $\begin{array}{c}C \\
97.83 \pm 1.55\end{array}$ & $\begin{array}{c}\mathrm{C} \\
0.63 \pm 0.09\end{array}$ \\
\hline $\begin{array}{l}\text { Cafergot } \\
(20 \mu \mathrm{g} / \mathrm{kg})\end{array}$ & $\underset{0.26 \pm 0.01}{A}$ & $\underset{0.1 \pm 0.01}{A}$ & $\begin{array}{c}\mathrm{A} \\
\mathbf{9 9 . 5 4} \pm 3.17\end{array}$ & $\underset{0.1 \pm 0.01}{A}$ \\
\hline Wild carrot oil $(0.1 \mathrm{ml})$ & $\begin{array}{c}A \\
0.24 \pm 0.01\end{array}$ & $\underset{0.16 \pm 0.02}{A}$ & $\underset{99.6 \pm 2.00}{A}$ & $\begin{array}{c}\mathrm{A} \\
0.00 \pm 0.00\end{array}$ \\
\hline
\end{tabular}

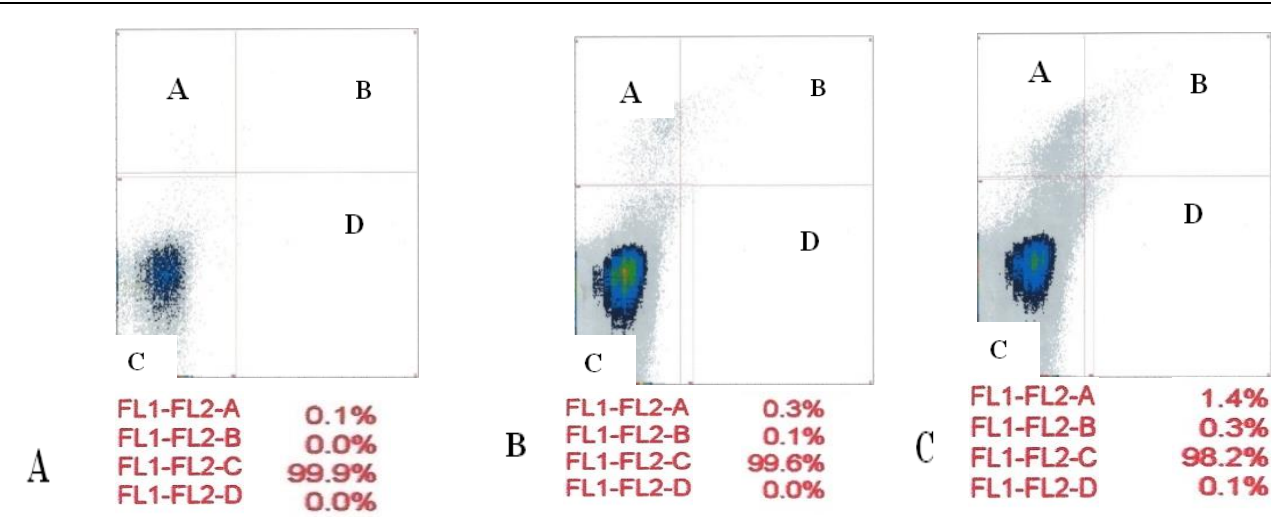
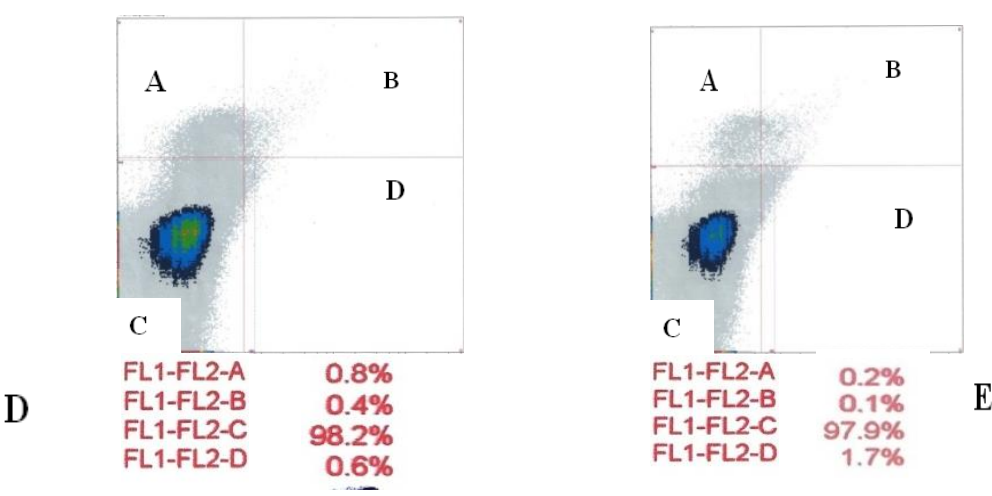

Fig.(2): Annexin $\mathrm{V}$ expression for mice induced apoptosis analysis. The labeling patterns inside quadrants indicate the percentage of A: necrotic cells(PI- positive/ Annexin V-negative); B: late apoptosis(PI-positve/ Annexin V-positive); C:Vital cells(PI-negative/ Annexine V- negative); D: apoptotic cells (PI-negative/ Annexine V-positive).The labeling patterns outside quadrants indicate the percentage of apoptotic cells control (A), wild carrot oil(B), Cafergot(C), contraceptive pills(D), MTX (E).

Most oral contraceptive pills contain a combination of estrogen (ethinylestradiol or mestranol) and progestin[17]. Concerning the progestin component formulations with a dose equivalent to $0.30 \mathrm{mg}$ norgestrel or more were categorized as high-progestin, while formulations with less than $0.30 \mathrm{mg}$ norgestrel or its equivalent were categorized as low-progestin formulations and Yasmin contraceptive pills belong to highprogestin formulations. An experimental study by [18] revealed that progestin induced apoptosis in the ovarian epithelium of macaques, leading to the hypothesis that the progestin component may be the major effect of 
combined oral contraceptives. Another study was achieved by [19] on monkeys that showed in general, few apoptotic cells were noted in the ovarian epithelium from either the control or estrogen-only-treated monkeys. In contrast, in progestin-treated monkeys, either those treated with combination ethinyl estradiol and levonorgestrelor with levonorgestrel alone, the ovarian epithelium contained numerous brown-staining apoptotic cells.

Excessive levels of gonadotropic hormones such as (FSH) and (LH) are also suggested to increase cell growth and inhibition of apoptosis [20], and oral contraceptives are known to suppress pituitary gonadotropin secretion. The primary mechanism of combined oral contraceptives is prevention of ovulation [21]. Combined oral contraceptives cause an ovulation by inhibiting production and secretion of both FSH and LH through steroid feedback on the pituitary gland. The estrogen component inhibits the release of FSH thereby suppressing the development of the ovarian follicle, while the progestin component inhibits the release of LH whereby ovulation is prevented [22].

At the cellular level, MTX is now firmly established to be a foliate antagonist that inhibits DNA and protein synthesis by inhibiting, respectively, thymidylatesynthetase (TYMS) and dihydrofolatesynthetase (DHFR), which is a crucial enzyme for folate metabolism and purine synthesis, resulting in lymphocyte apoptosis [23]. Further evidence supporting such results observed by[24]who showed that MTX also inhibits T cell activation and induces $\mathrm{T}$ cell apoptosis.

\section{Conclusion}

As conclusion the results of this work showed that, the oral contraceptive pills (Yasmin) was the most inducing contraceptive drugs to apoptosis, while Cafergot and wild carrot seeds oil were the least effective in comparison to the negative and positive control.

\section{References}

1.Daniel, R. and Mishell, Jr. (2011). Implantation, N.J., Merck Sharp and Dohme Corp, Whitehouse Station, USA.

2. Amy, C. (2010). Birth Control. In O'Reilly, Andrea, Encyclopedia of Motherhood. Thousand Oaks, Calif., Sage Publications, pp. 121-126.

3.Hanson, S.J. and Burke, A.E. (2010). Fertility Control: Contraception, Sterilization, and Abortion. In Hurt, K. J., Guile, M. W., Bienstock, J. L., Fox, H. E. and Wallach, E. E. The Johns Hopkins Manual of Gynecology and Obstetrics $\left(4^{\text {th }}\right.$ ed). Philadelphia,Wolters Kluwer Health/Lippincott Williams and Wilkins. pp. 382-395.

4.Dudley, P. (2010). Population and Society: An Introduction to Demography. Cambridge University Press. p.98.

5.Siberry, G. K. and Robert, I. (2000). The Harriet Lane Handbook, $15^{\text {th }}$ ed. Philadelphia, Mosby.

6.Jick, S.S. and Hernandez, R.K. (2011). Risk of non-fatal venous thromboembolism in women using oral contraceptives containing drospirenone compared with women using oral contraceptives containing levonorgestrel: case-control study using United States claims data. BMJ. 340.

7.Van Hylckama, V. A., Helmerhorst, F. M., Vandenbroucke, J.P., Doggen, C. J. and Rosendaal, F. R. (2009).The venous thrombotic risk of oral contraceptives, effects of estrogen dose and progestogen type: results of the MEGA case-control study. BMJ. 339.

8.Umadevi, M., Sampath Kumar, P.K., Debjit, B. and Duraivel, S. (2013). Medicinal plants with potential antifertility activity. J. of Med. Plants Studies. 1 (1):26-33.

9.Cain, S. L. (2012). The Benefits of the use of Daucuscarota in the herbal preparations: http://www.seminar.schoolofnaturalhealing.com/sites/seminar.schoolofnaturalhealing.com/files/Daucus\%20caro ta\%20-\%20Shelly\%20Cain.pdf

10.Langley, D. (1998). Exploiting the fungi: novel leads to new medicines. Mycologist.11: 165-166.

11.Matossian, M. K. (1989). Poisons of the Past: Molds, Epidemics, and History, Yale University Press, New Haven. CT.

12.Black, M.H. and Halmer, P. (2006). The Encyclopedia of Seeds: Science, Technology and Uses. CABI, Wallingford, UK. P.226.

13.Di Menna, M.E., Finch, S.C., Popay, A.J. and Smith, B.L. (2012). A review of the Neotyphodiumlolii/ Loliumperenne symbiosis and its associated effects on animal and plant health, with particular emphasis on ryegrassstaggers. Vet. J. 60:315-328.

14.Elmore, S. (2007). Apoptosis: a review of programmed cell death, Toxicologic Pathology. 35(4):495-516.

15.Dillon,S.R., Mancini, M., Rosen, A. and Schlissel, M.S. (2001). Annexin V Binds to Positively Selected B Cells. J. Immunol. 166:58-71.

16.Jitkaew, S., Witasp, E., Zhang, S., Kagan, V.E. and Fadeel, B. (2009). Induction of caspase- and reactive oxygen species independent phosphatidylserine externalization in primary human neutrophils: role in macrophage recognition and engulfment J. Leukoc. Biol. 85:427-437. 
17.Wilson, N.M., Laursen, M. and Lidegaard, O. (2012). Oral contraception in Denmark 1998-2010. ActaObstet. Gynecol. Scand. 91(7):810-815.

18.Rodriguez, G.C., Walmer, D.K., Cline, M., Krigman, H., Lessey, B.A. and Whitaker, R.S. (1998). Effect of progestin on the ovarian epithelium of macaques: cancer prevention through apoptosis? J. Soc. Gynecol. Investing. 5(5):271-276.

19.Gustavo, C., Rodriguez, N. P., Nagarsheth, K. L., Lee, R. C., David, K. W., Mark Cline, R. S., Whitaker, P. I., Andrew Berchuck, R. K. and Claude, L. H. (2002). JNCI J. Natl. Cancer Inst. 94(1): 50-60.

20.Konishi, I. (2006). Gonadotropins and ovarian carcinogenesis: a new era of basic research and its clinical implications. Int. J. Gynecol. Cancer.16(1):16-22.

21.Cibula, D., Gompel, A., Mueck, A.O., La Vecchia, C., Hannaford, P.C. and Skouby, S.O. (2010). Hormonal contraception andrisk of cancer. Hum.Report Update. 16(6):631-650.

22.Rivera, R.,Yacobson, I. and Grimes, D. (1999). The mechanism of action of hormonal contraceptives and intrauterine contraceptive devices. Americ. J. Obstet. Gynecol. 181(1):1263-1270.

23. Genestier, L., Paillot, R. and Fournel, S. (1998). Immunosuppressive properties of methotrexate: apoptosis and clonal deletion of activated peripheral T cells.J.Clin.Invest.,102:322-328.

24.Wessels, J. A., Huizinga, T. W. and Guchelaar, H. J. (2008). Recent insights in the pharmacological actions of methotrexate in the treatment of rheumatoid arthritis. Rheumatology. 47:249-255. 